\title{
5
}

\section{IFIP Working Group 3.5: using computers to support young learners}

\author{
David Benzie \\ College of St Mark \& St John \\ Plymouth \\ United Kingdom
}

\begin{abstract}
This paper outlines some of the major issues which IFIP Working Group 3.5 (Informatics in Elementary Education) is concerned with. Brief comments are made on the types of learning which we choose to support with computers, on the challenge to teacher educators posed by technology, on the effectiveness of national programmes and on contexts for learning. The paper concludes with brief details of two Professional Groups run at WCCE95 by members of the group.
\end{abstract}

Main conference themes: information technology, national policies, teacher education

Educational areas: elementary education, primary education

Study topics:

Secondary keywords: attitudes, classroom practice, curriculum development, curriculum policies, learning models, pedagogy, teaching methods 


\section{INTRODUCTION}

IFIP Working Group 3.5 was formed in 1983 and its work since then has focused on issues associated with the role of informatics in elementary (including preschool) education. Journals around the world which are devoted to informatics in education have reported on many exciting projects with elementary pupils and they have been a constant source of inspiration to members of the group. However, whichever country one considers, elementary education is almost invariably the poor relation when it comes to resources. This has meant that the widely acknowledged problems associated with attempts to generate large scale impact are particularly acute in the education sector this group focuses on.

It is in this context that this paper reviews some of the major challenges which face attempts to integrate principled and purposeful use of informatics into elementary education. This paper also gives a brief preview of two Professional Groups at WCCE95 where members of Working Group 3.5 are the lead organisers.

\section{COMPUTERS AND YOUNG LEARNERS: SOME CURRENT ISSUES}

Perhaps the greatest realization of all amongst those who have been involved with developing the role of informatics in education for the last fifteen years or so, has been that the task is, quite simply, very hard. Technological change occurs over time scales which are at least an order of magnitude shorter than social change time scales. For those who are captivated by technology, this has meant that the adrenaline and the excitement have continued to flow (stoking evangelical fervour on the way) while for others the safety of spectatorship has seemed rather more attractive. In the excitement there have been some who have looked thoughtfully over their shoulder at those sitting on the sidelines, and in so doing have come to realize that, at the very least, serious attention needs to be given to the following issues.

\section{Computers and learning}

Many authors have reported on the role which computers can play in motivating learners in a wide range of situations. A disappointingly large number of studies is somewhat suspect because of the unrecognized presence of Hawthorn effects, but even when allowance is made for that, it is clear that computers can play a much needed role in helping to maintain pupils interest and enthusiasm to learn. The ACOT research [1] provides convincing evidence that these enthusiasms are not short lived. That research, conducted in 
technology rich classrooms, also shows how profoundly computers affect the fundamentals of teaching and learning.

It is those fundamentals which now need to be openly discussed. We know that computers profoundly affect teaching and learning, but the nature of that affect is not predetermined. Marshall [2] alerted readers to the importance of epistemological considerations when seeking to bring about change in classroom practice. This debate is continued by Benzie [3] who shows how the framing of questions about the role of computers in education can affect the direction of change. Nicholson [4] provides us with a salutary example of how those whose first loyalty is not to education can pervert change by framing policies to meet political and economic agendas.

The whole debate about the sort of learning which we wish to promote is a critical one and it needs renewed attention. Hanor [5], for example, provides us with an excellent example of how thoughtful reflection which draws on educational insight can contribute to the debate on the nature of the contribution of computers to teaching and learning - in this case in the area of art education.

\section{The challenge to teacher education}

There is now no doubt about the magnitude of the challenge which computers have presented to those who are involved in both pre and in-service teacher education. Back in 1987 Wright [6] reported on the selfdoubt which was typical of pre-service teachers when faced by a computer. One might reasonably have expected things to have changed in the intervening years, but such change as has occurred is modest. In 1991 Dunn and Ridgway [7] reported on the somewhat patchy experiences with computers which students on school experience had in their final year of training. Their experiences were echoed by others in different settings [8, 9, 10]. By 1994 reports from Dunn and Ridgway [11] were more positive, but at the same time they conceded that the issue was one for the long term. Robinson [12] has argued effectively that we will only achieve change in the long term, if we ensure that both teacher educators and their students gain a better understanding of the concepts and procedures associated with change. There is a strong corpus of knowledge about change processes in education-but it is all too infrequently drawn on.

The situation with serving teachers is also problematic. We now know a lot about how to organize in-service training for the individual [13], how to structure it effectively at the school level and beyond [14] and how some of the barriers to change operate [15], but, as Benzie [16] observes, impact on classrooms still leaves a lot to be desired. A key difficulty seems to be the design and delivery of in-service programmes which are based on sound principles and so stand a reasonable chance of success while at the same time meeting a set of noneducational constraints. These issues apply to staff in 
teacher training institutions just as much as to schools-a point taken up by McDonald [17] and by Pratt [18].

\section{National Programmes: can these be effective?}

Governments around the world have frequently responded to the challenge of technology by initiating national programmes to introduce computers into mainstream education. The "me to" mentality has even meant that governments from developing countries have often added to their burden of debt in order to initiate such programmes even though the costs are large and the payoffs modest.

National programmes, while very popular, are frequently devised in ways which guarantee that success will be limited. Governments almost invariably ignore research evidence when devising programmes, preferring to work from a political agenda and from notions and questions which are generated in that sphere rather than in education. The consequence of this is a damaging distortion of focus-a point which is discussed by Nicholson [4] and Benzie [3].

Marshal [19] makes the further point that national programmes have also failed because of their mismatch with prevailing school culture. This is not to advocate that National Programmes should not be pursued. However, it is to advocate that the construction of such programmes has a sound theoretical base, reasonable (and negotiated) expectations and appropriate levels of resourcing. The latter is particularly problematic for programmes which focus on the use of computers in elementary schools because massive funding is invariably needed for the education sector which invariably is the poor relation.

\section{New contexts for learning}

Computers affect what is worth learning and how we learn. Additionally they are also beginning to have a profound effect on both the location and the timing of learning activities. Part of the change arises because of the introduction of computing technologies into the home and part because of the growth in computer based communications. Downes [20] outlines some of the challenges which technology in the home presents to teachers and she concludes that teachers would probably be well advised to gain a better understanding of the sort of lives their pupils are leading so that they can devise more appropriate school based learning activities.

Communications technologies are going to have a profound affect on the when and where of learning for teachers, students and pupils. In the case of the latter changed learning activities are more likely than alternate learning venues, but these will be no less profound for that. 
Baggott, Davis and Wright [21] provide us with a working example of how communications technologies can support professional development for teachers by increasing access to specialist resources. The possibilities in this area are very exciting, but once again past research on innovation can teach us a lot about how to make the most of what is on offer.

\section{PROFESSIONAL GROUPS AT WCCE95}

The following themes are addressed in WCCE95 as representing major issues of concern to WG 3.4:

- Teacher education for primary and secondary education

- Electronic Networks Between Schools: Our Earth - My Place

Brief descriptions of these two topics can be found with other IFIP Working Groups elsewhere in this volume. Additionally, members of WG 3.5 are the lead sponsors for the following professional groups:

Evaluation of computer use by pupils and teachers in the elementary school system

The work of this group will focus on the barriers to success encountered by teachers and pupils when using Computer Assisted Instruction (CAI) and Computer Assisted Learning (CAL). Some of the problems emanate from hardware which is not totally suited to the needs of teachers and pupils, and others are caused by 'unfriendly' hardware and software. Other issues which mitigate against efficient and effective use of information technology in the educational system, are related to personality, attitudinal and cognitive factors relating to both teachers and pupils.

Evaluation and assessment of the use of information technology in the elementary school system is of paramount importance in order to understand why efficiency and effectiveness are not universally achieved. An empirical analysis of the pedagogical, psychological and cognitive barriers to the successful use of information technology is a vital precondition for improving the utilization of computers and other technological aids in the educational process.

Integration of technology into pre-service training to better prepare new teachers for the 21st Century classroom

Students who are currently training to be teachers, will be teaching in societies where electronic information and communications technologies are pervasive. They will need to be able to use those technologies effectively and make responsible decisions about them. 
This Professional Group will focus on the issues, strategies, successes and problems of teacher educators as they seek to prepare students for tomorrow's classrooms. Discussion will centre on case studies from participants which will illustrate the critical issues being faced by teacher educators in countries around the world and the strategies which have been used in order to meet them.

\section{CONCLUDING REMARKS}

WCCE95 will be an exciting event and it will doubtless provide numerous examples of how computers can contribute to teaching and learning. We must, however, remember that the vast majority of learners still have very few opportunities to experience a technology enriched curriculum. The challenge is to translate possibilities into reality for all learners.

\section{REFERENCES}

1. Dwyer, D. (1994) Apple classrooms of tomorrow: What we've learned. Edutainment, August/September 1994, pp. 4-41.

2. Marshall, G. (1993) Informatics and changes in learning: the American dilemma and opposing epistemological perspectives and unanswered questions, in Informatics and Changes in Learning, (eds. Johnson, D. C. and Samways, B.), Elsevier Science Publishers, Amsterdam.

3. Benzie, D. (1995) The impact of our questions on IT policy and practice. Proceedings of WCCE95. Chapman and Hall, London.

4. Nicholson, P. (1995) Constructivist approaches to tackling economic anthropomorphism in Australian IT education. Proceedings of WCCE95. Chapman and Hall, London.

5. Hanor, J. (1994) Using an aesthetics lens to investigate young children's experiences with educational technology, in Exploring a New Partnership: Children, Teachers and Technology. (eds J. Wright \& D. Benzie), North Holland, Amsterdam, pp. 123-132.

6. Wright, J. and Campbell, P. (1987) Teacher training: a time for perspective taking. Education \& Computing, 3, pp. 275-280. 
7. Dunn, S. and Ridgway, J. (1991) Naked into the world: IT experiences on a final teaching practice-a second survey. Journal of Computer Assisted Learning, 7 (2) pp. 229-240.

8. Bosch, K. A. and Cardinale, L. (1993) Pre-service teachers perceptions of computer use during a field experience. Journal on Computing in Teacher Education, 10 (1) pp. 23-27.

9. Downes, T. (1993) Student teachers' experiences in using computers during teaching practice. Journal of Computer Assisted Learning, 9 (1) pp. 1733.

10. Handler, M. G. and Marshall, D. (1992) Preparing new teachers to use technology: One set of perceptions, in Technology and Teacher Education Annual-1992, (eds. Carey, D., Carey, R., Willis, D. A. and Willis, J.), AACE, Charlottesville, VA. pp. 386-388.

11. Dunn, S. and Ridgway, J. (1994) What CATE did: An exploration of the effects of the CATE criteria on students' use of information technology during teaching practice. Journal of Information Technology for Teacher Education, 3 (1) pp. 39-49.

12. Robinson, B. (1995) Teaching teachers to change: The place of change theory in the technology education of teachers, in Technology and Teacher Education Annual-1995, (eds. Willis, D. A., Robin, B. and Willis, B.), AACE, Charlottesville, VA. pp. 40-44.

13. Joyce, B. and Showers, B. (1980) Improving in-service training: the messages of research. Educational Leadership, 2, pp. 379-385.

14. Passey, D. and Ridgway, J. (1994) The development of informatics capability in elementary schools: What to do and how to make it work, in Exploring a New Partnership: Children, Teachers and Technology. (eds. Wright, J. and Benzie, D.), North Holland, Amsterdam, pp. 33-48.

15. Rhodes, V. and Cox, M. (1990) Current Practice and Policies for Using Computers in Primary Schools: Implications for Training. ESRC-InTER Occasional Paper InTER/15/90. University of Lancaster.

16. Benzie, D. (1995) IT in the UK. The Computing Teacher, 22 (5) pp. 46-48. 
17. McDonald, S. (1993) A model for staff development in Information Technology within initial teacher training institutions. Journal of Information Technology for Teacher Education, 2 (1) pp. 65-75.

18. Pratt, D. (1993) Effective strategies for information technology in teacher education: the use of an evolving permeation model. Journal of Information Technology for Teacher Education, 2 (1) pp. 53-61.

19. Marshall, G. (1994) Cautionary verses: Prospects and problems in achieving the aims of the computer revolution, in Exploring a New Partnership: Children, Teachers and Technology. . (eds. Wright, J. and Benzie, D.), North Holland, Amsterdam, pp. 9-20.

20. Downes, T. (1994) Children and electronic media in the home, in Exploring a New Partnership: Children, Teachers and Technology. (eds. Wright, J. and Benzie, D.), North Holland, Amsterdam, pp. 203-214,

21. Baggott, L., Davis, N. and Wright, B. (1995) Multimedia telecommunications: services for professional development, in Technology and Teacher Education Annual-1995, (eds. Willis, D. A., Robin, B. and Willis, B.), AACE, Charlottesville, VA. pp. 588-591. 